\title{
WHAT DO CONSUMERS LIKE TO SEE IN A CAUSE- RELATED MARKETING CAMPAIGN BOARD?
}

\author{
Kay-Tze Hong \\ Taylor's University \\ Siew-Imm Ng* \\ Universiti Putra Malaysia \\ Raja Nerina Raja Yusof \\ Universiti Putra Malaysia \\ Shivee Ranjanee Kaliappan \\ Universiti Putra Malaysia
}

\begin{abstract}
The purpose of this study is to discover elements or contents of a Cause-Related Marketing (CRM) campaign's communication board that may attract consumers to participate in the CRM program. This study focuses on the design of a CRM campaign communication board exclusively based on the perceptions of Malaysian consumers in the hypermarket context. Besides that, this study also identifies social causes applicable for hypermarkets in Malaysia. Employing a qualitative approach, the data in this study were obtained through focus group interviews and were analysed using a content analysis method. The study has identified seven themes that Malaysian consumers would like to see in a communication board, which were hypermarket initiative, communication, tagline and logos, timeframe, types of support (funds handled by NGOs), company-cause fit, and CRM products that are not limited to local products. These elements, if incorporated into a CRM communication board, will appeal to Malaysian consumers. The findings provide insights into the study of CRM communication board content that appeals to hypermarket consumers in Malaysia. This study also contributed to the CRM literature by exploring the applicability of a fairly new social cause (e.g. supporting underprivileged individuals) that can be championed and supported by the hypermarket. This research also offers practical implications for hypermarket managers. Hypermarkets can incorporate the seven elements (hypermarket initiative, communication, tagline and logos, timeframe, types of support, company-cause fit, and CRM products that are not limited to local products) while designing a CRM communication board.
\end{abstract}

Keywords: Cause-related Marketing, Hypermarkets, Corporate Social Responsibility, CRM Communication Board, Participation Intention.

Received: 25 June 2019

Accepted: 30 December 2020

https://doi.org/10.33736/ijbs.3182.2021

\footnotetext{
* Corresponding author: University Putra Malaysia, Jalan UPM, 43400, Serdang, Selangor Malaysia; Tel: +6018-2343323; Email: imm_ns@upm.edu.my
} 


\section{INTRODUCTION}

Corporate social responsibility (CSR) has emerged as a popular concept (Schramm-Klein, Morschett, \& Swoboda, 2015) wherein organizations consider the concern of the entire society by taking responsibility for the effects of their actions or they support activities that are taken to improve the well-being of their stakeholders (Rahim, Jalaludin, \& Tajaddin, 2011). CRM is a marketing approach where a company supports a worthy cause or donates to a social cause and concurrently hopes to increase the sales of their products or services as a result of their efforts (Anuar \& Mohamad, 2011). CRM has been used as a popular business strategy to gain greater competitive advantage and consumer support (Mimouni Chaabane \& Parguel, 2016). However, its use in the hypermarkets is less prevalent.

Malaysia's retail sector is recognised as the main contributor to the nation's gross national income, and after the large format retail sub-sector was liberalised in 1995, hypermarkets have encountered major growth (PEMANDU, 2010). Hence, hypermarkets have been quick to dominate the Malaysian retail landscape since the first hypermarket, Makro, was introduced in Malaysia in 1993 (Lee, 2004). As a developing nation, Malaysia has been continuously experiencing an increase in hypermarket outlets year after year (Hassan, Rahman \& Sadir, 2015). For that reason, hypermarkets are becoming more competitive in their marketing strategies related to product quality, price and services. This becomes more challenging as consumers' personal consumption may have reduced ("Supermarkets And Hypermarkets In Malaysia Going Through Consolidation", 2019). Hence, it is logical that hypermarkets revert their resources to CSR-related activities. As such, engaging in CRM activities may better attract consumers when consumers are given the option to contribute back to the society while also buying the products they want or need (Gupta \& Pirsch, 2008).

Recent CRM studies differ from this current study in three ways. First, CRM have yet to be introduce in Malaysian hypermarkets representing their own corporate brands (i.e. AeonBig). Usually, CRM that has been run by hypermarkets previously were initiated by specific products brands that the hypermarkets carried (i.e. TOP detergent in AeonBig). As loyalty towards a specific product brand and hypermarket brands are different, thus this may result in different consumers' response towards CRM in hypermarkets. Therefore, uncovering exclusively the Malaysian consumers' response towards introducing CRM in hypermarkets is pertinent. Second, discovering elements in a CRM communication board for a hypermarket context in Malaysia is still underreported. For example, Chang (2012) drew a comparison between cause-focused and product-focused advertising on the effectiveness of CRM. Although there are some studies that have examined message content or message framing in the context of various CSR-related activities (e.g Thaler \& Helmig, 2013), none have yet explored the overall content of a CRM communication board that is favourable to Malaysian consumers in the hypermarket context.

Third, the social causes that are usually used to examine CRM occurrence in the literature have focused on diseases like Alzheimer's and cancer (Robinson, Irmak, \& Jayachandran, 2012), children's wellbeing, such as the Unicef (Mimouni et al., 2016), wildlife and environmental issues, like the SPCA, and the WWF (Chéron, Kohlbacher, \& Kusuma, 2012), as well as cause that support local produce (Yee, Imm \& Hwa, 2018). There is a gap in addressing the applicability of social causes championed by NGOs that focus on developing new entrepreneurs from under-privileged groups. This can become a social cause to gain support for hypermarkets. 
In short, the aim of this study is to identify elements of a CRM campaign's communication board that consumers would like to see when participating in a CRM program. Besides that, this study also seeks to explore the applicability of a relatively new social cause (e.g. supporting underprivileged individuals) that can be championed and supported by the hypermarket. Furthermore, it is also pertinent to examine CRM in a hypermarket context in Malaysia as CRM have yet to be run by Malaysian hypermarket's own corporate brands, hence this study is relevant. Specifically, this paper contributes to the CRM literature by closing the research gaps that pertain to those elements of a CRM campaign communication board that appeal to consumers in Malaysia and customers who believe in the cause championed by the hypermarket can be persuaded to purchase from the hypermarket. Thus, this paper explicitly provides managerial recommendations on the design of a CRM campaign communication board for hypermarkets in Malaysia.

\section{LITERATURE REVIEW}

CSR refers to a company's consideration of its community's concern by taking responsibility for the effect of their actions or activities on stakeholders and the environment (Rahim et al., 2011). CSR can be studied from many different perspectives and contexts. For example, there was an examination of CSR activities' impact on retailers' performance (Schramm-Klein et al., 2015), the study of consumers' perception on CSR aspects in evaluating and purchasing grocery brands (Anselmsson \& Johansson, 2007), and intention to participate in a CRM campaign (Yee et al., 2018).

CRM falls under the umbrella of CSR. CRM is defined by Varadarajan and Menon (1988) as a course of action that formulates and applies marketing activities as an offer from the company to donate a specified sum of capital to a chosen cause when customers join in an exchange of revenueproviding activities that comply with both organizational and individual objectives. This study focuses on the examination of CRM because CRM is seen as the most creative, cost-effective and popular marketing tactic that has made substantial impact on charitable groups, consumers and businesses (Galan Ladero, Galera Casquet, \& Singh, 2015). Many retail companies in Malaysia has also adopted CRM. To illustrate, for every 30 QL eggs purchased, QL Poultry Farms Sdn Bhd will donate 50 cents to the IJN Foundation (QL Resources Bhd, 2012). As a whole, CRM can help companies draw in more consumers, boost sales, and heighten their favourable image to the public (Anuar \& Mohamad, 2011; Barone, Norman, \& Miyazaki, 2007).

A CRM campaign is considered successful when consumer response is favourable toward the company and the designated social cause. That response can be measured by consumers' participation intention, purchasing intention and favourable attitude towards the designated campaign (Hajjat, 2003). There are several factors that can influence consumers' responses to a CRM campaign. First, brand-cause fit can influence consumers' attitudes positively (Barone et al., 2007). Mendini, Peter, and Gibbert (2018) defines brand-cause fit as the similarity between the brand and the cause. Buil, Martinez and Montaner (2012) mentioned that the degree of brand-cause fit impacts the credibility of CRM advertising campaigns and consumers' emotional perceptions. For instance, Myers, Kwon, and Forsythe (2012) reported that consumers are more likely to perceive that the brand has a fundamental interest in the cause and in turn will form more favourable CRM campaign attitude when the cause and the brand fit together. 
Second, it was discovered that consumers had a more positive evaluation of a CRM campaign which was a long term program compared to one that was short term (Cui et al., 2003), as shortterm CRM campaigns are perceived to be less sincere and only interested in increasing short-term sales (Van den Brink, Odekerken-Schröder, \& Pauwels, 2006). Third, the types of support in a CRM campaign also influence consumers' evaluations of the CRM program. It was reported that consumers had a more positive evaluation of a CRM campaign that adopts non-transaction-based support (e.g. the company itself plays a role as a facilitator or is an additional contributor) compared to transaction-based support (e.g., dollar support, percentage support) (Cui et al., 2003). Similarly, a CRM campaign is perceived to be more effortful when the type of support is product donation rather than a cash donation (Ellen, Mohr, \& Webb, 2000).

Fourth, consumers' decision to engage in a CRM campaign is determined by the firm's motives. Consumers will offer more positive evaluations of a CRM campaign when the company portrays its altruistic motives and will evaluate the firm more negatively when the campaign is perceived as having only profit-oriented motives (Moosmayer \& Fuljahn, 2013). A study showed that when a brand is perceived to have more intrinsic motivations (altruistic) for participating in the CRM campaign, consumers had more favourable CRM campaign attitudes (Myers et al., 2012). Fifth, the distance between donation activity and consumers will also influence the consumers' CRM participation. For instance, it was found that consumers have a more favourable evaluation of a CRM campaign when it is supporting a local cause rather than a national or global cause (Hou, Du \& Li, 2008; Hoeffler \& Keller, 2002). Sixth, consumers' response toward a CRM program is affected by the nature of the social cause. The studies reported that consumers' evaluation of a CRM campaign is more positive when that campaign supports a short-term disaster cause which requires urgent help rather than an ongoing cause which can wait (Ellen et al., 2000; Cui et al., 2003).

Seventh, communicating CSR activities effectively to consumers is also important in order to engage consumers in that company's CSR initiatives. Hammad, El-Bassiouny, Paul, and Mukhopadhyay (2014) stated that it is vital to clearly and explicitly illustrate the reason why the CSR initiatives run by companies are essential for consumers rather than being subtle and understated in that communication. The majority of consumers prefer CSR communication to be factual and not imprecise writing style. For instance, the statement " $\mathrm{CO} 2$ emissions have reduced by 15 percent and ten years from now it will be reduced by 50 percent" is preferred to "great effort is given to reduce CO2 emissions" (Schmeltz, 2012). Eighth, CRM campaign that frames its message as a dominant cause will receive a more positive attitude from consumers (Samu \& Wymer, 2009). As framing is also one of the ways to communicate CSR activities to consumers, Chang (2012) found that a cause-focused advertisement is more effective for hedonic product promotion and a product-orientated advertisement is more effective for utilitarian product promotion.

A study found that the strongest motivator for audience attitudes and intentions to donate to a charity is their level of favourability toward the charity (Wymer, McDonald, \& Scaife, 2014). Thus, consumers will participate in a CRM campaign when they perceive that the cause or the supporting company is their personal interest. From the theoretical perspective of personal relevance theory, participation in the CRM campaign is determined by the degree that consumers can personally relate to the cause as well as their approval of the supporting company and its advertisement content 
(Antil, 1984). For instance, some consumers are more attracted to social causes with high visibility (Varadarajan \& Menon, 1988) or a campaign that supports a local cause (Hou et al., 2008).

The above reviews suggest that various contents can drive consumers' participation in a CRM campaign. For example, when consumers ascribe the CRM advertisement message to external factors (i.e. advertiser self-interest) rather than internal factors (i.e. advertiser concern for and willingness to help those in need), consumer's evaluations of the advertised products is less favourable (Chang, 2012). There are thus three literature gaps; 1) Consumers' responses towards CRM introduced in hypermarkets' own corporate brand name is unidentified 2) CRM campaign content applicable for hypermarket is under-researched and 3) Social causes applicable for hypermarkets are not known. This study addresses these three gaps by identifying content and social causes applicable for hypermarkets which is vital for hypermarket management to design an effective CRM campaign.

\section{SAMPLE SIZE, METHODS AND PROCEDURES}

A qualitative method is not intended to provide conclusive evidence but it is conducted with the expectation that additional research will be needed to provide more conclusive evidence (Zikmund, Babin, Carr, \& Griffin, 2013). Focus groups are used as an exploratory technique and its intend is not to generalize but to determine the range, and not to make statements about the population but to provide insights about how people in the groups perceive a situation (Krueger \& Casey, 2000). Therefore, a qualitative study and focus group interview approach was adopted for the purpose to explore the perception of consumers as there are limited prior researches in Malaysia regarding CRM in the context of hypermarkets.

Lincoln and Guba (1985) suggested sampling until redundancy is reached or when it reaches a point of saturation for a qualitative approach. Generally, Saunders, Lewis and Thornhill (2012) proposed a range of 8 to 25 samples to achieve the saturation point. For instance, an exploratory study on promotional planning in UK regional shopping centres has utilized an interview approach by interviewing 4 managers (Warnaby \& Yip, 2005). Therefore, in this study, data saturation was achieved after the second round of focus group interview, since no new themes emerged from the second focus group. In the end, sample size used in this study was 10 (5 participants in each focus group interview).

Participants in the focus group interviews were selected using judgmental sampling as participants in a qualitative research design are not selected to offer an average opinion rather, are chosen because of their unique experiences and expertise (Merriam, 2009). Hence, the judgmental criteria used for subject selection were (1) Participants were decision-makers for grocery purchases; (2) Participants had purchased from hypermarkets before; and (3) Participants were familiar with the hypermarket environment. The focus group interviews were conducted in the faculty's meeting rooms and lasted for approximately two hours for each focus group. To identify the elements of a CRM communication board that would motivate consumers' participation in CRM, specific questions that was derived and in compliance with the techniques and subjects in these studies or references (e.g. Terano, Yahya, Mohamed, \& Saimin, 2014, Abu and Roslin, 2008, Merriam, 2009) were asked during the focus group interviews, such as the following:

-- "Would you participate in CRM? Why and Why not?" 
-- "Are there any features or elements that you would like to see on a CRM communication board?",

--"What are the attributes or traits of a CRM communication board that would attract your attention or motivate you to participate?"

Advertisements were put up to invite participants and anyone who fulfilled the selection criteria were chosen. After that, appointments with the chosen participants were made through telephone contacts and emails. A written informed consent was obtained from the participants and the focus group interviews were recorded using an audio voice recorder. The focus group interviews were facilitated by a moderator and a note taker was at present to observe and take down important points throughout the interview process. After that, the interviews recorded were replayed and transcribed as soon as the sessions were completed. A RM100 cash voucher was given to participants as a token of appreciation for their time and effort in the study. The transcribed focus group interviews data were coded and interpreted into key thematic findings. The data was then analysed by adopting a content analysis method, which is a systematic and replicable method for compressing many words of text into a smaller number of content groups using explicit rules of coding (Stemler, 2001). Under the content analysis method, this study used a priori coding, where the themes were determined from the literature before the data collection. When experts (three marketing researchers) agreed on the groupings themes then that coding were applied to the data.

\subsection{Profiles of Participants}

According to Table 1, these participants belonged to a varied set of demographics in terms of gender (5 Males and 5 Females), race (6 Malay, 2 Chinese, and 2 Indian), and life experiences of family background and values. The majority of the participants were age $41-50$ years (50\%) and all had achieved an education level of a Master's degree or higher. Additionally, they met specific criteria like 1) decision-maker in purchasing household groceries, 2) purchased before from a hypermarket, and 3) are familiar with the hypermarket sector.

Table 1: Summary of Participants' Profiles

\begin{tabular}{ccccc}
\hline \hline Participants & Gender & Ethnicity & Age & Education Level \\
\hline Participant 1 & Female & Chinese & $41-50$ & Master Degree and Above \\
Participant 2 & Male & Chinese & $41-50$ & Master Degree and Above \\
Participant 3 & Male & Indian & $51-60$ & Master Degree and Above \\
Participant 4 & Male & Indian & $51-60$ & Master Degree and Above \\
Participant 5 & Female & Malay & $41-50$ & Master Degree and Above \\
Participant 6 & Male & Malay & $51-60$ & Master Degree and Above \\
Participant 7 & Female & Malay & $41-50$ & Master Degree and Above \\
Participant 8 & Female & Malay & $31-40$ & Master Degree and Above \\
Participant 9 & Female & Malay & $41-50$ & Master Degree and Above \\
Participant 10 & Male & Malay & $31-40$ & Master Degree and Above \\
\hline \hline
\end{tabular}

Source: Focus Group Interviews 


\section{RESULTS}

Participants has suggested several elements on the CRM communication board that would motivate consumers in joining a CRM campaign. These were categorised into seven common themes: Hypermarket initiative, communication, tagline and logos, time frame, types of support (funds handled by NGO), company-cause fit, and CRM products not limited to local products.

\subsection{Theme 1 - Hypermarket Initiative}

Consumers will be more inclined to support a CRM campaign when that campaign is initiated by the hypermarket itself and not other parties (i.e. government). This decision shows that the hypermarket is sincere in helping the community, and thus more consumers will be attracted to these hypermarkets.

"I will go for that initiative taken by the hypermarkets and not the initiative taken by the government because I know there is a hidden agenda behind it, whatever the government is involved." - Participant 3

"Yes, if it is purely initiated by the hypermarket, I'm okay because they are more accountable. Chances are they will do something about the campaign." - Participant 3

\subsection{Theme 2 - Communication}

Communication here refers to the features or facets that appear on the communication board. Participants suggested including more facts and pictures on the communication board, as it is crucial for consumers to know that the hypermarket is actually doing something real. These visual features will communicate more effectively to the consumers and help them decide whether the campaign is worth supporting. In short, the features on the communication board should be heartrending in order to draw consumers' intention toward supporting the CRM campaign.

"Some facts and figures as well as photos on the NGO (CASE) are helpful. If I am the customer, and I see these pictures, then I know these are the beneficiaries of the campaign, and it will warm my heart." - Participant 10

"If the hypermarket is helping the underprivileged individuals, then I want to know how is the hypermarket really wanting to help these underprivileged individuals. So there must be a story behind it. It's not just a CRM and a label affix on the communication board. I want to know the story for why hypermarkets want to help these underprivileged individuals with content that touches my heart; otherwise, it is meaningless." - Participant 2

\subsection{Theme 3 - Tagline and Logos}

Tagline refers as a slogan that is used in an advertisement and logos are symbols that are designed to represent an organization to recognize its business, products, and values. Consumers are attracted to taglines that touch their hearts and logos or tagline might influence the consumers' perception towards the CRM campaign and the hypermarket running the campaign. Taglines that appeal to Malaysians are desirable. 
"Maybe we can appeal to the generosity of Malaysian, Malaysian are quite generous, maybe you can create a tag line that appeals to their wanting to give, whether it is a big amount or a small amount. Generally Malaysian want to give. So, if you can come out with something that touches that, I think they are willing to part away with their money." - Participant 6

\subsection{Theme 4-Timeframe (Short Term vs. Long Term)}

Timeframe refers to the length or frequency of support for a social cause linked to the CRM campaign. Most respondents prefer a longer time frame campaign, as length shows that the campaign is sincere and not just trying to achieve its own short-term profit objectives. The respondents did not trust a campaign that is short-term because they perceived that these kinds of campaigns are not genuine in terms of helping a social cause.

"For me as a consumer, I like to look at the long-term sustainability of the project. Not a onetime go. Now the funds are ready for NGO and then gone, leaving the NGO with financial struggles. Not those kinds of short-term things. I'm not into those short-term things." - Participant 2

\subsection{Theme 5 - Types of Support (CRM handled by NGO)}

Types of support here refer to whether the donation is contributed to the social cause as cash or products. The results from the focus group show that most participants prefer a donation contributed in the form of products or one that is channelled directly to an NGO. This is because the participants are quite sceptical about where the money will go if the donation was made in cash. The participants are also worried that the money will not reach the intended target groups that really are in need of help if cash donation is the choice. Therefore, cash that is not handled by the hypermarket (hypermarket does not give cash directly to the needy) but rather channelled to an NGO is preferred.

"I give in kinds nowadays like food, for instance, some who run shelter homes are living a wealthy life, so when they say they only receive cash, I am very suspicious."'- Participant 3

"For example, a campaign to support local products, buying local products and sending them directly to shelter homes, will attract your attention and attract your participation?" - Interviewer "To some certain extent, yes. Because it all goes back to whether I use that product, no point that I buy and I don't use it." - Participant 1

"Let's say I buy RM100 worth of particular products and that RM100 worth of products will be sent to the shelter homes. I am okay with that." - Participant 3

\subsection{Theme 6-Company-Cause Fit}

A social cause having a good fit with the company means that there is an association between that social cause and the company's brand image, product line, target market and its position in that market (Varadarajan \& Menon, 1988). Most participants feel that the social cause supported by a hypermarket should be consistent with that hypermarket's core business or somehow be associated with the hypermarket's values and philosophies. 
"I'm not sure, maybe social causes related to helping Malaysians instead of international groups are more attention grabbing, since the hypermarket is operating in Malaysia. - Participant 8

"Should be related to their business activities like Starbucks' helping Third World countries by buying their coffee. As for hypermarkets' suppliers are entrepreneurs, it is good if hypermarkets could select a cause that could help develop entrepreneurs" - Participant 5

\subsection{Theme 7 - CRM Products Not Being Limited to Local Products}

Participants felt that the products related to the CRM campaign should not only be connected to local products, but also should be applicable to all products in the hypermarkets. This is because most participants have difficulty identifying locally made products, which thus, makes it difficult and maybe even a barrier for customers who wish to participate in a CRM campaign. Similarly, participants will only purchase the few overseas brands that are familiar to them and will not consider purchasing local products they have not tried before. Therefore, the CRM's products should be extended to all products in the hypermarket, regardless of the local brand or international brand products.

"I will not try to buy local products especially when I am already familiar with a particular foreign brand." - Participant 1

"I think it is good to mix the international brands and non-international brands products; if you put forth only the non-international products, then you might not be able to get more consumers to participate in the CRM campaign." - Participant 5

\subsection{Developing a Hypothetical CRM Communication Board}

Basing on the themes identified, a hypothetical communication board was created. Table 2 shows the main themes generated from the focus group interviews and the corresponding content integrated in the CRM communication board. In addition, the frequency of themes highlighted by participants was also shown in Table 2.

As a result, the final communication board was created, as shown in Figure 1. Centre for Advancement of Business, Innovation and Social Entrepreneur (CASE) is a NGO that aims to improve the living standard of individuals from poverty ridden areas in Malaysia by spreading entrepreneurial skills and knowledge. The choice of a NGO was made based on two literature gaps. First, the limited use of a NGO with a social cause that supports underprivileged individuals. Second, the social cause is in line with the core business of the hypermarket. With the development of more entrepreneurs by CASE, the pool of local entrepreneurs may supply more local products to be carry by the hypermarkets. Thus, CASE's social cause will be developing entrepreneurs from underprivileged individuals, indeed in line with the hypermarket's core business as the retail partner of local entrepreneurs. 
Table 2: Appealing Elements for a CRM Communication Board

\begin{tabular}{|c|c|c|c|}
\hline Themes & Narration Evidence & $\begin{array}{l}\text { Participants } \\
\text { Coding }\end{array}$ & $\begin{array}{c}\text { Reflection on the } \\
\text { Communication Board }\end{array}$ \\
\hline $\begin{array}{l}\text { Hypermarket } \\
\text { Initiatives }\end{array}$ & $\begin{array}{l}\text { "Yes, if it is purely initiated by the } \\
\text { hypermarket, I'm okay because they } \\
\text { are more accountable." - } \\
\text { Participant } 3\end{array}$ & $\begin{array}{l}1,2,3,7,9 \\
10\end{array}$ & $\begin{array}{l}\text { Hypermarket effort was } \\
\text { shown, where the } \\
\text { hypermarket was the } \\
\text { organizer of the campaign. }\end{array}$ \\
\hline Communication & $\begin{array}{l}\text { "Some facts and figures as well as } \\
\text { photos of the NGO (CASE) are } \\
\text { helpful. If I see these pictures, then I } \\
\text { know these are the beneficiaries of } \\
\text { the campaign, and it will warm my } \\
\text { heart." - Participant } 10\end{array}$ & $\begin{array}{l}2,3,4,5,6,9 \\
10\end{array}$ & $\begin{array}{l}\text { - Pictures and a clear NGO } \\
\text { logo (CASE) was inserted. } \\
\text { - Stories about the } \\
\text { campaign were listed. }\end{array}$ \\
\hline $\begin{array}{l}\text { Tagline and } \\
\text { Logos }\end{array}$ & $\begin{array}{l}\text { "Maybe we can appeal to the } \\
\text { generosity of Malaysians, maybe } \\
\text { you can create a tag line that } \\
\text { appeals to their wanting to give. } \\
\text { Generally, Malaysians want to give. } \\
\text { So if you can come up with } \\
\text { something that touches that, I think } \\
\text { they are willing to part with their } \\
\text { money." - Participant } 6\end{array}$ & $\begin{array}{l}1,3,4,6,7,9 \\
10\end{array}$ & $\begin{array}{l}\text { - A heart-rending tagline } \\
\text { was added: "For a better } \\
\text { economy, a better country, } \\
\text { for us, for our children and } \\
\text { the generations to come". }\end{array}$ \\
\hline Time Frame & $\begin{array}{l}\text { "For me as a consumer, I like to } \\
\text { look at the long-term sustainability } \\
\text { of the project. Not a one-time go. } \\
\text { I'm not into those short- term } \\
\text { things." - Participant } 2\end{array}$ & $2,3,5,7$ & $\begin{array}{l}\text { - The campaign was } \\
\text { designed as a long- term } \\
\text { program, e.g. "over the next } \\
\text { ten years" }\end{array}$ \\
\hline $\begin{array}{l}\text { Types of } \\
\text { Support (Funds } \\
\text { handled by } \\
\text { NGO) }\end{array}$ & $\begin{array}{l}\text { "I give in kinds nowadays like food, } \\
\text { for instance, so those that runs } \\
\text { shelter homes are living a wealthy } \\
\text { life. When they say they only receive } \\
\text { cash, I am very suspicious."- } \\
\text { Participant } 3\end{array}$ & $\begin{array}{l}1,2,3,4,5,7 \\
10\end{array}$ & $\begin{array}{l}\text { - The campaign was } \\
\text { designed where cash would } \\
\text { not be handled by the } \\
\text { hypermarket but be } \\
\text { channelled by the NGO } \\
\text { (CASE). }\end{array}$ \\
\hline $\begin{array}{l}\text { Company- } \\
\text { Cause Fit }\end{array}$ & $\begin{array}{l}\text { "Should be related to their business } \\
\text { activities. As for hypermarkets" } \\
\text { supplies are entrepreneurs, it is } \\
\text { good if hypermarkets could select a } \\
\text { cause that could help develop } \\
\text { entrepreneurs" - Participant } 5\end{array}$ & $3,4,5,7,8$ & $\begin{array}{l}\text { - The social cause selected } \\
\text { was related to the } \\
\text { hypermarket's businesses, } \\
\text { e.g. helping to develop } \\
\text { underprivileged individuals } \\
\text { who wish to live } \\
\text { independently through } \\
\text { entrepreneurial activity. }\end{array}$ \\
\hline $\begin{array}{l}\text { CRM products } \\
\text { not limited to } \\
\text { local products. }\end{array}$ & $\begin{array}{l}\text { "I think is good to mix the } \\
\text { international brands and non- } \\
\text { international brands products, if you } \\
\text { put only the non-international } \\
\text { brands products that tie to CRM, } \\
\text { then you might not be able to get } \\
\text { more consumers to participate in the } \\
\text { CRM campaign." - Participant } 5\end{array}$ & $\begin{array}{l}1,2,3,4,5,8 \\
9\end{array}$ & $\begin{array}{l}\text { - The campaign was } \\
\text { designed to be applicable to } \\
\text { all products in the } \\
\text { hypermarket. E.g. "Any } \\
\text { products' sales......" }\end{array}$ \\
\hline
\end{tabular}


Figure 1: A Hypothetical CRM Campaign's Communication Board

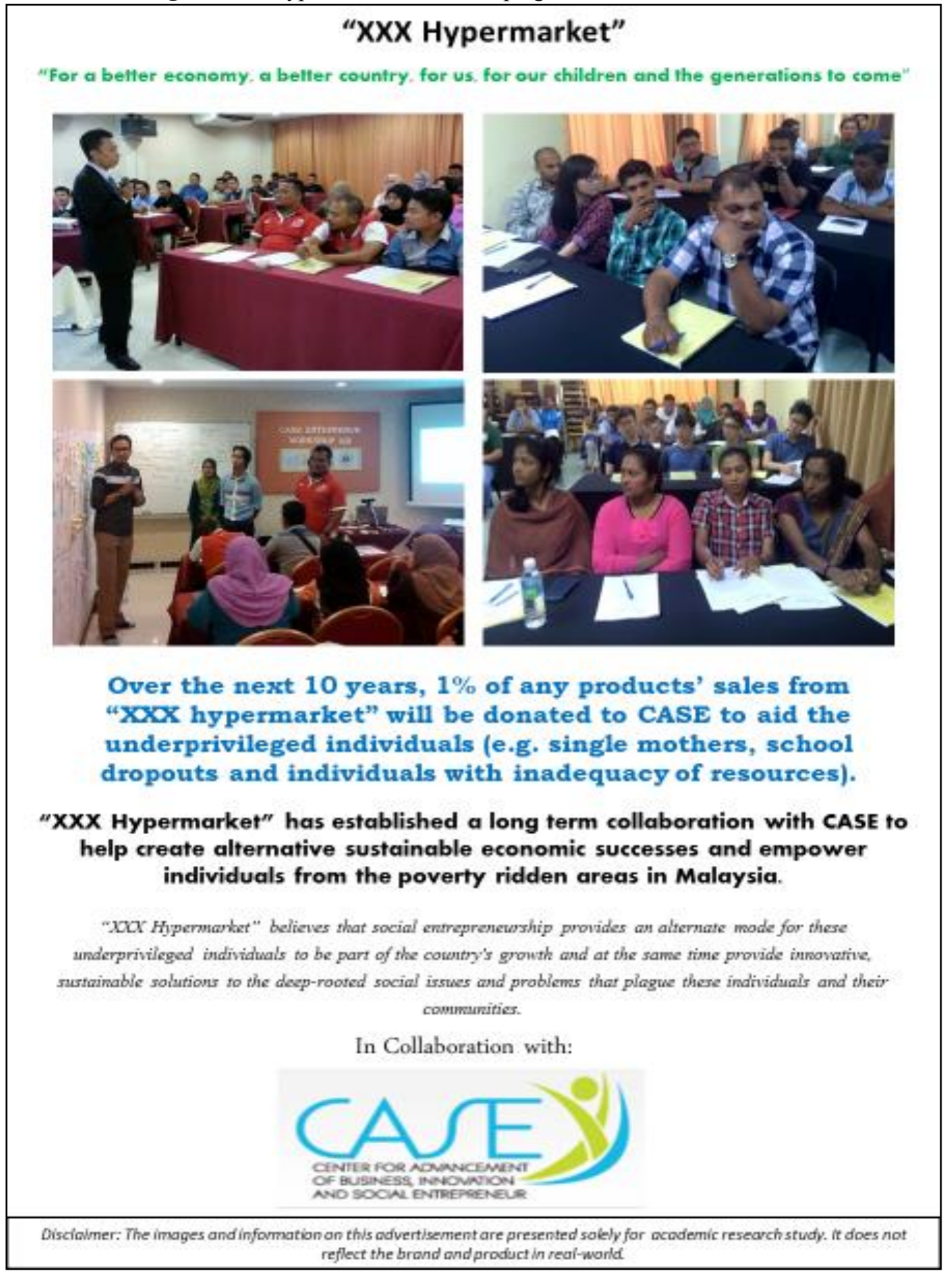




\section{DISCUSSION}

Following the a priori coding method, themes were ascertained from literature before the data collection and after the themes were agree by the experts, then only the coding was applied to the data. Hence, Table 3 summarized the themes related to elements of a CRM communication board as reported in the literature. Then the content was categorized according to those themes. As can be seen from Table 3, the literature identified eight themes for CRM communication board elements. However, focus group data indicated only five of these are applicable in the Malaysia hypermarket context, while two new themes undocumented in the literature emerged.

The results for the CRM communication campaign elements concurred with five elements identified in earlier studies. First, in line with Schmeltz (2012), it is vital to clearly and explicitly illustrate the reason why a CRM campaign is run by hypermarkets. Grau and Folse (2007) showed that consumers preferred that a CRM communication board were positively framed (i.e positive influences on other lives) compared to negatively frame (i.e. death rates). This is similar with the findings of the focus group interview participants, who preferred the CRM communication board to appear positive in terms of sharing pictures and warm taglines. Second, communication board should appear cause dominance. In this study, the participants suggested including the NGO's logo, taglines, and pictures to take up more than $75 \%$ of the space in the communication board, a suggestion that is in line with Samu and Wymer's (2009) study which demonstrated that cause dominance is likely to generate positive responses compared to brand dominance. Third, consistent with Varadarajan and Menon's (1988) study, the participants prefer to participate and support a CRM campaign that involves a long-term relationship with the charitable cause rather than a shortterm one. Alhouti, Johnson and Holloway (2016) discovered that when a CSR charitable cause have a long-term impact, consumers will perceive that the CSR activities involved by the company is authentic.

Fourth, in line with Ellen et al., (2000), consumers favour participating in a CRM campaign where they are sure that the money collected from that campaign will be channelled to a reliable party. In this case, the donations collected from the CRM campaign will be directed to the NGO (CASE) and will not be handled by the hypermarket. This will reduce consumers' scepticism towards the CRM campaign. Lastly, in line with the studies by Hou et al., (2008) and Wymer and Drollinger (2015), the findings in this study show that since hypermarkets are engaged with local suppliers who are also entrepreneurs, a CRM campaign with the cause of developing underprivileged individuals as entrepreneurs is appropriate. This is also consistent with the study of Kim, Sung and Lee (2012), which discovered that consumers will perceive a high fit between the company and the non-profit organization when there is a fit in the dimension of familiarity and activity, thus this high fit will lead consumers to identify the company as being more public-serving. In turn, consumers are more likely to have favourable attitude and purchase intention towards the company (Moosmayer \& Fuljahn, 2013).

Interestingly, two new themes were found as a result of this study. First, the study found that Malaysian consumers prefer a CRM campaign that is initiated by the hypermarket itself, where the message presents the initiative that is being taken by the hypermarket and not by any government department. Exclusive to the Malaysian context, consumers do not favour the SME-related authority logo or having any governmental logo placed on the communication board. This is due to the issue of trust where most respondents felt that placing these logos on the communication 
board will infer some hidden agenda of the government or the SME body. Anuar, Omar, and Mohamad (2014) found that in general Malaysian consumers have some level of scepticism towards a CRM campaign. Thus, in this study, consumers prefer to have the CRM campaign to be solely initiated by the hypermarket rather than any other associations.

Second, the qualitative findings also suggest that a CRM campaign should not limit its designated products to just local products or any specific product, but instead apply it to all products sold in the hypermarkets. Most respondents felt that the CRM campaign will not be effective if the CRM products are confined to local products. This is due to the fact that many consumers are not able to distinguish between local products and non-local products, thus making it more difficult for consumers to participate in the CRM campaign. Tapping on Davis (1986, 1989, 1993)'s Technology Acceptance Model (TAM), "Perceived Ease of Use" is one of the key factor that will affect an individual's intention. In this case, perceived ease of use could signify that participating in a CRM campaign should be free of effort. Hence, a CRM campaign which is linked to hypermarket-wide products is more suitable. This may reduce the confusion and trouble for consumers in searching for a specific product that is tied to the CRM and lessen the complexity of joining a CRM campaign.

Table 3: Elements or Contents of a CRM communication board

\begin{tabular}{|c|c|c|c|c|c|c|c|}
\hline & & & & Ex & nples & & \\
\hline 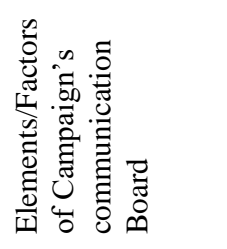 & 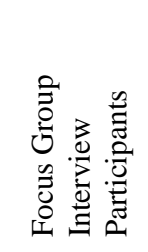 & 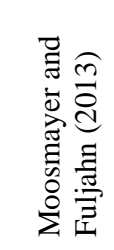 &  & 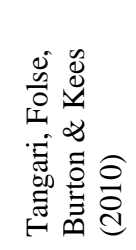 & 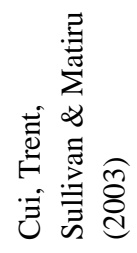 & 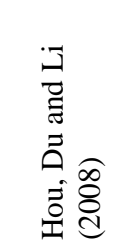 &  \\
\hline Communication & $\checkmark$ & - & - & $\checkmark$ & - & - & $\checkmark$ \\
\hline $\begin{array}{l}\text { Campaign } \\
\text { Duration (Time } \\
\text { Frame) }\end{array}$ & $\checkmark$ & - & $\checkmark$ & - & $\checkmark$ & - & - \\
\hline Type of Support & $\checkmark$ & - & - & - & $\checkmark$ & - & - \\
\hline $\begin{array}{l}\text { Company-Cause } \\
\text { Fit }\end{array}$ & $\checkmark$ & $\checkmark$ & $\checkmark$ & - & - & $\checkmark$ & $\checkmark$ \\
\hline $\begin{array}{l}\text { Tagline and } \\
\text { Logos (Cause } \\
\text { Dominance) }\end{array}$ & $\checkmark$ & - & - & - & - & - & $\checkmark$ \\
\hline Firm Motives & - & $\checkmark$ & - & - & - & - & - \\
\hline $\begin{array}{l}\text { Donation } \\
\text { Proximity }\end{array}$ & - & - & $\checkmark$ & $\checkmark$ & $\checkmark$ & $\checkmark$ & - \\
\hline $\begin{array}{l}\text { Nature of the } \\
\text { Cause }\end{array}$ & - & - & - & - & $\checkmark$ & $\checkmark$ & - \\
\hline Initiatives & $\checkmark$ & - & - & - & - & - & - \\
\hline $\begin{array}{l}\text { CRM Products } \\
\text { Not limited to } \\
\text { Local Products }\end{array}$ & $\checkmark$ & - & - & - & - & - & - \\
\hline
\end{tabular}




\section{IMPLICATIONS}

This study contributes to the CRM literature in several theoretical ways. First, this study uncovered CRM communication board content that appeals to hypermarket consumers in Malaysia. When a CRM communication board is designed properly and favourably to reflect consumers' preferences, it will focus on seven themes: Hypermarket initiative, communication, tagline and logos, time frame, types of support (funds handled by NGO), company-cause fit and CRM products not limited to local products. Then consumers will be more likely to participate in the CRM campaign. Thus, this study adds values to the CRM literature which focuses on the development of a CRM communication board for hypermarkets in Malaysia.

Second, this study contributed to the CRM literature by exploring the applicability of a fairly new social cause championed by a NGO in the CRM literature that can then be used as a social cause supported by the hypermarket. In this case, the "supporting underprivileged individuals" cause was selected for this study. Underprivileged individuals are individuals that are lack of resources or support (i.e. single mothers or school dropouts) who are poor or face social issues and wish to improve their living standard by starting small businesses in their own community (CASE, 2014). The choice supporting underprivileged individuals is an appropriate cause for a developing country like Malaysia because of that nation's inequality of income distribution ("Malaysia's Income Distribution Inequality 'Still High'", 2013). Hence, these underprivileged individuals require additional attention to help them support themselves. The "Supporting underprivileged individuals" cause was found to be relevant in a Malaysian hypermarket context based on results from this study.

Third, two new insights emerged from the Malaysian data on CRM communication board content that were not captured in literature. First, the study found that Malaysian consumers would rather have a CRM campaign that is run by the hypermarket itself and not by other corporations (i.e. SME authority or government body). Second, the findings also suggest that a CRM campaign should not limit CRM products to just local products but apply it to hypermarket-wide products. These two new insights add value to CRM literature that country-specific contents are important to acknowledge.

In terms of managerial implications, this study found seven key themes that hypermarkets can applied or incorporate when designing a CRM campaign communication board. For example, when designing a CRM campaign, hypermarkets management should ensure that the social cause they want to support in the CRM campaign aligns well with the hypermarket's core business, offering, brand concept, visions and/or target markets and supports a local cause (a NGO from the local vicinity). In addition, hypermarket management should consider the duration of the campaign when organizing any CRM program, as a long-term campaign (e.g., 10 years or more) is viewed more favourably by consumers than a short-term campaign (e.g., just a few months or 1-2 years). Hypermarket management should also put more attention on message framing in order to communicate the CRM campaign clearly and convincingly to consumers (Chang, 2012; Tangari et al., 2010), including adding creative taglines that touch the heart of locals, such as "For a better economy, a better country, for us, for our children and the generation to come". 


\section{LIMITATIONS AND FUTURE RESEARCH}

As with all research, this study is confined by certain limitations, hence suggesting promising areas for further research. First, the present study has used content analysis method and collected data through focus groups. Focus group is an exploratory research, where its goal is to formulate more precise questions that can address in future research (Neuman, 2014), thus focus group is performed with the expectation that additional research will be needed to provide more conclusive evidence (Zikmund et al., 2013). Hence, future studies could use other techniques, such as in-depth interview, observation method or the survey method to further validate the results of this study. Second, this study only examines one retail format (hypermarkets), the findings may not apply to other retail formats as the results may differ. Future research can conduct similar studies on other retail formats such as departmental stores, convenience stores or specialties stores to generalize the results on different retail formats in Malaysia. Lastly, as the sample of this study is collected from among Malaysians only, generalisations to citizens of other countries is limited because of cultural differences in consumer behaviour. Future studies can consider comparing the findings of this study with those from other countries for a cross-cultural comparison (e.g. emerging versus developed countries).

\section{CONCLUSION}

A CRM program benefits both hypermarkets and consumers. Consumers benefit as the CRM program let them contribute to a charitable cause they support while buying groceries. Hypermarkets benefit from higher sales, since customers are now more motivated to buy from them and not another source. This paper is one of a small number of studies that has explicitly focused on the elements of designing a CRM campaign communication board that would attract consumers to participate in CRM. CRM can be used as a differentiation strategy for hypermarkets wherein customers who believe in the cause that is being championed by the hypermarket will be drawn to purchase from that hypermarket.

Employing a qualitative approach, data were obtained through focus group interviews and this study suggested that when hypermarkets or companies are designing a CRM campaign communication board, such elements as hypermarket initiative, communication, taglines and logos, time frame, types of support (funds handled by an NGO), company-cause fit and CRM products that are not limited to local products are essential to utilize and integrate into a CRM communication board. This study has also identified the applicability of a new social cause (e.g. supporting underprivileged individuals) that can be championed and supported by the hypermarket. Ultimately, an appealing CRM communication board is much more likely to result in higher CRM participation, and thus can be a positive outcome for both hypermarkets and social causes.

\section{ACKNOWLEDGEMENT}

The authors would like to acknowledge Universiti Putra Malaysia for the support given. 


\section{REFERENCES}

Abu, N. K., \& Roslin, R. M. (2008), Identifying service quality dimensions by understanding consumer preferences in the Malaysian grocery retail sector, Unitar E-journal, 4(2), 5767.

Alhouti, S., Johnson, C. M., \& Holloway, B. B. (2016). Corporate social responsibility authenticity: Investigating its antecedents and outcomes. Journal of Business Research, 69(3), 12421249.

Anselmsson, J., \& Johansson, U. (2007), Corporate social responsibility and the positioning of grocery brands: An exploratory study of retailer and manufacturer brands at point of purchase. International Journal of Retail \& Distribution Management, 35(10), 835-856.

Antil, J. H. (1984). Conceptualization and operationalization of involvement. Advances in Consumer Research, 11, 203-209.

Anuar, M. M., \& Mohamad, O. (2011). Examining the effects of cause-proximity and gender on consumers' response to cause-related marketing: evidence from Malaysia. International Journal of Marketing Studies, 3(3), 174-181.

Anuar, M. M., Omar, K., \& Mohamad, O. (2014). Does Skepticism Influence Consumers Intention to Purchase Cause-related Products? Global Journal of Business and Social Science, 1(9), 94-98.

Barone, M. J., Norman, A. T., \& Miyazaki, A. D. (2007). Consumer response to retailer use of cause-related marketing: Is more fit better? Journal of Retailing, 83(4), 437-445.

Buil, I., Martinez, E., \& Montaner, T. (2012). The influence of marketing actions with cause in the attitude toward the brand. Notebooks of Economy and Direction of the Company, 15(2), 84-93.

Chang, C. (2012). The effectiveness of advertising that leverages sponsorship and cause-related marketing: A contingency model. International Journal of Advertising, 31(2), 317-338.

Chang, C. T. (2012). Missing ingredients in cause-related advertising: The right formula of execution style and cause framing. International Journal of Advertising, 31(2), 231-256.

Chéron, E., Kohlbacher, F., \& Kusuma, K. (2012). The effects of brand-cause fit and campaign duration on consumer perception of cause-related marketing in Japan. Journal of Consumer Marketing, 29(5), 357-368.

Cui, Y., Trent, E. S., Sullivan, P. M., \& Matiru, G. N. (2003). Cause-related marketing: How generation $\mathrm{Y}$ responds. International Journal of Retail \& Distribution Management, 31(6), 310-320.

Davis, F. D. (1986). Technology acceptance model for empirically testing new end-user information systems: Theory and results, MA, USA: Massachussetts Institute of Technology.

Davis, F. D. (1989). Perceived usefulness, perceived ease of use, and user acceptance of information technology. MIS Quarterly, 13, 319-339.

Davis, F. D. (1993). User acceptance of information technology: System characteristics, user perceptions and behavioral impacts. International Journal of Man-Machine Studies, 38, 475-487.

Ellen, P. S., Mohr, L. A., \& Webb, D. J. (2000). Charitable programs and the retailer: do they mix? Journal of retailing, 76(3), 393-406.

Galan Ladero, M. M., Galera Casquet, C., \& Singh, J. (2015). Understanding factors influencing consumer attitudes toward cause-related marketing. International Journal of Nonprofit and Voluntary Sector Marketing, 20(1), 2-70. 
Grau, S. L. \& Folse, J. A. G. (2007). Cause-related marketing (CRM): The influence of donation proximity and message-framing cues on the less-involved consumer. Journal of Advertising, 36(4), 19-33.

Gupta, S., \& Pirsch, J. (2008). The influence of a retailer's corporate social responsibility program on re-conceptualizing store image. Journal of retailing and consumer services, 15(6), $516-526$

Hajjat, M. M. (2003). Effect of cause-related marketing on attitudes and purchase intentions: the moderating role of cause involvement and donation size. Journal of Nonprofit \& Public Sector Marketing, 11(1), 93-109.

Hammad, H., El-Bassiouny, N., Paul, P., \& Mukhopadhyay, K. (2014). Antecedents and consequences of consumers' attitudinal dispositions toward cause-related marketing in Egypt. Journal of Islamic Marketing, 5(3), 414-445.

Hassan, H., Rahman, M. S. \& Sade, A. B. (2015). Shopping Day and Time Preferences of Malaysian Hypermarket Consumers. Australian Journal of Business and Economic Studies, 1(1), 61-68.

Hoeffler, S. \& Keller, K. (2002). Building brand equity through corporate societal marketing. Journal of Public Policy \& Marketing, 21(1), 78-89.

Hou, J., Du, L. \& Li, J. (2008). Cause's attributes influencing consumer's purchasing intention: empirical evidence from China. Asia Pacific Journal of Marketing and Logistics, 20(4), 363-380.

Kim, N., Sung, Y., \& Lee, M. (2012). Consumer evaluations of social alliances: The effects of perceived fit between companies and non-profit organizations. Journal of business ethics, 109(2), 163-174.

Krueger, R. A., \& Casey, M. A. (2000). Focus Groups: A Practical Guide for Applied Research, ( $3^{\text {rd }}$ ed.). Thousand Oaks, CA: Sage Publications.

Lee, C. (2004). Centre on Regulation and Competition. Working Paper Series Paper No. 68. Competition Policy in Malaysia, Centre on Regulation and Competition.

Lincoln, Y. S. \& Guba, E. G. (1985). Naturalistic inquiry. Thousand Oaks, CA: Sage.

Mendini, M., Peter, P. C., \& Gibbert, M. (2018). The dual-process model of similarity in causerelated marketing: How taxonomic versus thematic partnerships reduce skepticism and increase purchase willingness. Journal of Business Research, 91, 195-204.

Merriam, S. B. (2009). Qualitative Research: A Guide to Design and Implementation. San Francisco: Jossey-Bass.

Mimouni Chaabane, A. \& Parguel, B. (2016). The double-edge effect of retailers' cause-related marketing: When scepticism cools the warm-glow effect. International Journal of Retail \& Distribution Management, 44(6), 607-626.

Moosmayer, D. C. \& Fuljahn, A. (2013). Corporate motive and fit in cause related marketing. Journal of Product \& Brand Management, 22(3), 200-207.

Myers, B., Kwon, W. S., \& Forsythe, S. (2012). Creating effective cause-related marketing campaigns: The role of cause-brand fit, campaign news source, and perceived motivations. Clothing and Textiles Research Journal, 30(3), 167-182.

Neuman, W. L. (2014), Social Research Methods: Qualitative and Quantitative Approaches. $\left(7^{\text {th }}\right.$ ed.). USA: Pearson New International Edition.

Performance Management and Delivery Unit (PEMANDU) (2010). Economic Transformation Programme, A Roadmap for Malaysia. Retrieved from https://policy.asiapacificenergy.org/sites/default/files/ETP.pdf 
QL Resources Bhd. (2012). What's New: A Good Heart Starts with QL Eggs. Retrieved from http://www.qleggs.com/whats-new.php

Rahim, R. A., Jalaludin, F. W. \& Tajuddin, K. (2011). The importance of corporate social responsibility on consumer behaviour in Malaysia. Asian academy of management journal, 16(1), 119-139.

Robinson, S. R., Irmak, C. \& Jayachandran, S. (2012). Choice of cause in cause-related marketing. Journal of Marketing, 76(4), 126-139.

Samu, S. \& Wymer, W. (2009). The effect of fit and dominance in cause marketing communications. Journal of Business Research, 62(4), 432-440.

Saunders, M., Lewis, P., \& Thornhill, A. (2012). Research Methods for Business Students (6 ${ }^{\text {th }}$ Ed.). Italy: Pearson Education Limited.

Schmeltz, L. (2012). Consumer-oriented CSR communication: focusing on ability or morality? Corporate Communications: An International Journal, 17(1), 29-49.

Schramm-Klein, H., Morschett, D., \& Swoboda, B. (2015). Retailer corporate social responsibility: Shedding light on CSR's impact on profit of intermediaries in marketing channels. International Journal of Retail \& Distribution Management, 43(4/5), 403-431.

Stemler, S. (2001). An overview of content analysis. Practical Assessment, Research \& Evaluation, 7(17), 1-6. Retrieved from http://pareonline.net/getvn.asp?v=7\&n=17

Tangari, A. H., Folse, J. A. G., Burton, S. \& Kees, J. (2010). The moderating influence of consumers' temporal orientation on the framing of societal needs and corporate responses in cause-related marketing campaigns. Journal of Advertising, 39(2), 35-50.

Terano, R., Yahya, R., Mohamed, Z., \& Saimin, S. B. (2014). Consumers' Shopping Preferences for Retail Format Choice Between Modern and Traditional Retails in Malaysia. Journal of Food Products Marketing, 20, 179-192.

Thaler, J., \& Helmig, B. (2013). Promoting good behavior: does social and temporal framing make a difference? VOLUNTAS: International Journal of Voluntary and Nonprofit Organizations, 24(4), 1006-1036.

The Center for Advancement of Business, Innovation and Social Entrepreneur (CASE). (2014). Retrieved from http://projects.gobran.my/case/index.html

Malaysia's income distribution inequality 'still high'. (2013, August 3). The Star. Retrieved from https://www.thestar.com.my/business/business-news/2013/08/03/malaysias-incomedistribution-inequality-still-high/

Supermarkets and hypermarkets in Malaysia going through consolidation. (2019, September 17). The Star. Retrieved from https://www.thestar.com.my/business/business-news/2019/09/ 17/supermarkets-and-hypermarkets-in-malaysia-going-through-consolidation

Van den Brink, D., Odekerken-Schröder, G., \& Pauwels, P. (2006). The effect of strategic and tactical cause-related marketing on consumers' brand loyalty. Journal of Consumer Marketing, 23(1), 15-25.

Varadarajan, P. R., \& Menon, A. (1988). Cause-related marketing: A coalignment of marketing strategy and corporate philanthropy.The Journal of Marketing, 52(3), 58-74.

Warnaby, G., \& Yip, K. M. (2005). Promotional planning in UK regional shopping centres: an exploratory study. Marketing Intelligence \& Planning, 23(1), 43-57.

Wymer, W., \& Drollinger, T. (2015). Charity Appeals Using Celebrity Endorsers: Celebrity attributes most predictive of audience donation intentions. VOLUNTAS: International Journal of Voluntary and Nonprofit Organizations, 26(6), 2694-2717. 
Wymer, W., McDonald, K., \& Scaife, W. (2014). Effects of corporate support of a charity on public perceptions of the charity. VOLUNTAS: International Journal of Voluntary and Nonprofit Organizations, 25(6), 1388-1416.

Yee, W. F., Imm, N. S., \& Hwa, L. C. (2018). Cause-Related Marketing: It's Influence on Consumers' Choice of Hypermarket. International Journal of Business \& Society, 19(3), 616-636.

Zikmund, W. G., Babin, B. J., Carr, J. C., \& Griffin, M. (2013). Business Research Method (9 ${ }^{\text {th }}$ Ed.). Singapore: South-Western, Cengage Learning. 